\title{
PENGAMBILAN KEPUTUSAN PADA LAKI-LAKI YANG MENIKAH DENGAN WANITA TUNA WICARA
}

\section{DECISION MAKING OF THE MEN WHO WEW MARRIED TO WOMEN WITH SPEECH DISABILITY}

\author{
Oleh \\ Visi Laksani ${ }^{1}$ \\ Dyah Siti Septiningsih ${ }^{2}$
}

\begin{abstract}
This study aims to examine the stages of decision making in men who were married to women with speech disability. The method used in this study is a qualitative method with a case study approach. The data is obtained through semi-structured interviews with 3 normal male participants who were married to women who are deaf from birth with marriage age of 3 months to 5 years. The credibility of the data used by researcher is member check. Creswell data analysis is used in this study. The result showed that each participant passed through the form of the decision making stage which was influenced by social factor, personal factor, and psychological factor. $H$ and $S$ married to women with speech disability because of their own free will, while A married because of an arranged marriage.
\end{abstract}

Keywords: Decision Making; Male; Speech disability.

\begin{abstract}
ABSTRAK
Penelitian ini bertujuan untuk mengkaji tahapan pengambilan keputusan pada laki-laki yang menikah dengan wanita tuna wicara. Metode yang digunakan dalam penelitian ini adalah metode kualitatif dengan pendekatan studi kasus. Data penelitian diperoleh melalui wawancara semi berstruktur kepada 3 partisipan laki-laki normal yang sudah menikah dengan wanita tuna wicara sedari lahir dengan umur pernikahan 3 bulan sampai 5 tahun dan 3 informan, yaitu orang tua dan saudara. Kredibilitas data yang digunakan oleh peneliti yaitu menggunakan membercek. Penelitian ini menggunakan analisis data Creswell. Hasil penelitian menunjukkan bahwa setiap partisipan melewati bentuk dari tahapan pengambilan keputusan yang dipengaruhi oleh faktor sosial, faktor pribadi, dan faktor psikologis. Pada $\mathrm{H}$ dan $\mathrm{S}$ menikah dengan wanita tuna wicara karena atas keinginan sendiri, sedangkan pada A menikah dengan wanaita tuna wicara karena dijodohkan.
\end{abstract}

Kata Kunci: Pengambilan Keputusan; Laki-laki; Tuna Wicara.

\section{PENDAHULUAN}

Manusia memiliki beberapa hal yang penting di dalam kehidupan, yaitu mampu berpikir, mendengar, dan berbicara. Bagi manusia memiliki kemampuan berbahasa dan pendengaran yang baik adalah hal yang sangat penting untuk berkomunikasi dengan individu lain. Menurut Sardjono (2005), tuna wicara merupakan salah satu kelainan dalam pengucapan atau artikulasi bahasa maupun suara, sehingga mengakibatkan kesulitan dalam berkomunikasi lisan dalam lingkungannya. Janji setia yang terucap merupakan sesuatu yang tidak mudah untuk diucapkan, maka perlu adanya suatu keberanian bagi seseorang untuk memutuskan menikah (Kertamuda, 2009).

\footnotetext{
${ }^{1}$ Fakultas Psikologi - Universitas Muhammadiyah Purwokerto, visi.laksani@yahoo.com

${ }^{2}$ Fakultas Psikologi - Universitas Muhammadiyah Purwokerto
} 
Pada penelitian sebelumnya, Manggala (2016) menjelaskan bahwa menikah dengan disabilitas adalah sebuah keputusan sendiri dalam melakukan pernikahan, karena adanya penolakan dari lingkungan keluarga besar terutama orang tua atau mertua. Dalam mengambil keputusan menikah, tidak banyak pihak-pihak yang terlibat didalamnya.

Pengambilan keputusan muncul karena berdasarkan sebuah masalah, adanya ketidaksesuaian antara masalah saat ini dan keadaan yang diinginkan serta membutuhkan pertimbangan untuk membuat beberapa tindakan alternatif (Robbins dan Judge, 2013). Tahapan yang digunakan dalam pengambilan keputusan menurut Kotler (2012), yaitu identifikasi masalah, pencarian dan analisis data, pembuatan alternatif kebijakan, pemilihan salah satu alternatif terbaik, pelaksanaan keputusan, serta pemantauan dan pengevaluasian hasil pelaksanaan.

Daya tarik fisik dan memiliki kemampuan berbicara yang baik berpengaruh besar pada kesan pertama, kriteria ini penting untuk pemilihan pasangan hingga ke jenjang pernikahan selamanya. Pada umumnya, laki-laki normal akan lebih selektif dalam mengambil keputusan untuk memlilih pasangan. Laki-laki akan mudah menentukan pilihan dalam menyeleksi baik secara fisik maupun material atau faktor ekonomi. Oleh karena itu peneliti menjadi tertarik melaksanakan penelitian untuk menggali lebih dalam bagaimana tahapan pengambilan keputusan pada laki-laki yang menikah dengan wanita tuna wicara.

\section{METODE PENELITIAN}

Penelitian ini menggunakan metode penelitian kualitatif (qualitative research). Penelitian kualitatif adalah penelitian yang menggunakan metode- metode untuk lebih mendalami dan memahami makna yang ada dari suatu permasalahan sosial atau manusia dari individu (Creswell, 2013).

\section{HASIL DAN PEMBAHASAN}

\section{Identifikasi Masalah}

Identifikasi masalah merupakan tahapan atau proses mengenali masalah serta mempelajari masalah yang dialami oleh individu (Kotler, 2012). Berdasarkan dari hasil temuan penelitian, hal yang menjadi suatu permasalahan bagi partisipan adalah keadaan dan kekurangan yang dialami oleh istri. Kesukaan yang terjadi pada orang lain yaitu dengan sikap positif dan daya tarik seseorang. $\mathrm{H}$ dan A berpendapat bahwa kritera yang sesuai untuk dijadikan istri adalah yang memiliki fisik normal. Berbeda dengan S, menikah dengan istri tuna wicara bukanlah suatu permasalahan yang dikhawatirkan, melainkan menikah adalah salah satu tujuan hidup yang ingin dicapai. Disisi lain, S mendapat tanggapan dari orang lain ketika hendak menikah dengan istri, yaitu anak S mempermasalahkan kondisi fisik yang dialami oleh istri S. Apabila mendapat infromasi yang kurang jelas biasanya menyebabkan individu mengalami konflik sementara dan timbul perasaan ragu-ragu dengan apa yang telah dipercaya. Individu akan mulai mencari alternatif yang lainnya jika memberikan tanggapan positif setelah keputusan pertama.

Kemudian menurut Miller \& Pearlman (2015) mengatakan bahwa penampilan fisik salah satu hal yang menjadikan seseorang mengambil keputusan, yaitu yang berhubungan dengan penampilan luar seseorang yang mudah dinilai oleh orang lain. Berpenampilan menarik akan lebih disukai dan lebih baik dibandingkan dengan orang yang berpenampilan kurang menarik. Seiring dengan berjalannya waktu, $\mathrm{H}$ dan A dapat menerima apa adanya kekurangan yang dialami istri, mensyukuri kekurangan yang ada dengan lapang dada, dan menjalani dengan rasa ikhlas, sebab $\mathrm{H}$ dan $\mathrm{A}$ percaya bahwa jodoh sudah ditentukan oleh Allah SWT. Semua orang termasuk wanita tuna wicara atau orang yang memiliki kekurangan fisik memiliki hak yang sama, salah 
satunya adalah hak untuk menikah baik dengan laki-laki normal maupun laki-laki yang memiliki kekurangan fisik. Tuna wicara merupakan salah satu kelainan dalam pengucapan atau artikulasi bahasa maupun suara, sehingga mengakibatkan kesulitan dalam berkomunikasi lisan dalam lingkungannya (Sardjono, 2005). Penampilan fisik salah satu hal yang menjadikan seseorang mengambil keputusan, yaitu yang berhubungan dengan penampilan luar seseorang yang mudah dinilai oleh orang lain. Daya tarik fisik dan memiliki kemampuan berbicara yang baik akan berpengaruh besar pada kesan pertama, kriteria ini penting untuk pemilihan pasangan hingga ke jenjang pernikahan selamanya.

Hal tersebut ditemukan pada ketiga partisipan pada penelitian ini, yaitu lakilaki normal yang menikah dengan wanita tuna wicara. Usia hubungan rumah tangga ketiga partisipan masing-masing berbeda, $\mathrm{H}$ sudah menjalani rumah tangga pernikahan selama lima tahun, A lima tahun, dan S tiga bulan. Kasus tersebut menjadi suatu hal yang menarik dalam penelitian, bahwa seorang laki-laki normal pada umumnya akan lebih selektif dalam mengambil keputusan untuk memlilih pasangan. Laki-laki akan mudah menentukan pilihan dalam menyeleksi baik secara fisik maupun material atau faktor ekonomi.

\section{Pencarian Informasi dan Analisis Data}

Pencarian informasi dan analisis data adalah tahapan pengambilan keputusan yang diharapkan dapat mengumpulkan dan menganalisis data yang dapat membantu memecahkan suatu masalah (Kotler, 2012). Status menikah dengan wanita tuna wicara menjadi suatu permasalahan, salah satunya berdasarkan dari orang lain baik tanggapan positif maupun negatif. Pada tahap ini yaitu mulai mencari berbagai alternatif tindakan serta meminta saran dari orang lain untuk menghadapi masalahnya. Tanggapan tersebut berasal dari keluarga, tetangga, dan saudara. Keluarga dan tetangga $\mathrm{H}$ merasa senang dan tidak ada yang mencibir atau mempermasalahkan mengenai keinginan $\mathrm{H}$ menikah dengan wanita tuna wicara. Keluarga dan tetangga beranggapan bahwa hal tersebut adalah jodoh yang telah diberikan dari Allah SWT dan harus mampu untuk menerima dengan ikhlas apa yang telah diberikan. A memperoleh informasi mengenai pernikahan dari tetangga untuk segera menikah supaya dapat mengetahui bagaimana kehidupan setelah menikah. Tetangga A menanggapi hal tersebut dengan senang, walaupun ada beberapa yang berbicara negatif dan saudara A menjadikan hal tersebut sebagai lelucon mengenai keputusannya. Keluarga A menanggapi dengan biasa saja atas keinginan yang A inginkan dan orang tua A beropini untuk tetap sabar menjalani kehidupan sehari-hari dalam suatu hubungan pernikahan dengan istri yang tuna wicara. Untuk $\mathrm{S}$, tanggapan orang lain mengenai menikah dengan istri tuna wicara tidak dijadikan suatu masalah oleh keluarga dan tetangga $S$. Keinginan $S$ untuk menikah mendapat dukungan dan penerimaan dari saudara dan tetangga $S$ terhadap keputusan yang diambil untuk menikah dengan wanita tuna wicara. Namun hal tersebut merupakan permasalahan bagi anak $S$, yaitu anak $S$ tidak mengizinkan $S$ untuk menikah lagi, dengan alasan ibu kandungnya baru saja meninggal dan anak $\mathrm{S}$ merasa malu karena belum menikah memiliki ibu sambung yang tuna wicara. $\mathrm{S}$ tidak ada pandangan lagi apabila melihat wanita lain yang memiliki fisik sempurna, 
karena $\mathrm{S}$ sudah memiliki istri yang ditakdirkan dari Tuhan. Kebahagiaan yang $\mathrm{S}$ ketahui tentang sebuah pernikahan, yaitu saling bekerja sama, rukun rumah tangganya, dan saling menghormati.

Pengalaman masa lalu dan keadaan ekonomi A menjadi alasan dan berpengaruh untuk memilih menikah dengan istri tuna wicara, karena saat menjalani hubungan dengan wanita normal, A sering merasakan sakit hati karena mantan kekasihnya menginginkan laki-laki yang kaya dan mapan, sedangkan A hanya bekerja seadanya dan berlatar belakang dari keluarga yang kurang mampu. A menikah dengan istri karena dijodohkan yang berawal dari permintaan orang tua istri A kepada teman A. Dan A berharap bahwa menikah dengan wanita tuna wicara akan memperbaiki keadaan ekonomi keluarga A dengan dampak resiko yang harus A terima setelah menikah dengan wanita tuna wicara. Kemudian pengalaman masa lalu yang dialami oleh $\mathrm{S}$ adalah setelah meninggalnya istri pertama yang mengakibatkan $\mathrm{S}$ merasa kesepian, kurangnya kebutuhan biologis dengan istri, dan tidak ada yang mengurus kehidupan dan rumah $\mathrm{S}$. Berbeda dengan $\mathrm{H}$ yang tidak memiliki pengalaman masa lalu atau pengalaman buruk untuk memilih menikah dengan wanita tuna wicara. Faktor usia $\mathrm{H}$ yang sudah cukup matang dan siap untuk menikah menjadi alasan memilih menikah dengan wnaita tuna wicara, karena $\mathrm{H}$ percaya bahwa menikah dengan istri adalah jodoh yang diberikan oleh Tuhan dengan dorongan keyakinan dari informasi yang $\mathrm{H}$ peroleh terkait pernikahan yang bersifat positif.

\section{Pembuatan Alternatif-alternatif Kebijakan}

Pembuatan alternatif-alternatif kebijakan merupakan perincian suatu masalah yang disusun secara baik dan benar serta memikirkan cara penyelesaiannya. Sumber utama yang dijadikan individu sebagai tempat membuat alternatif kebijakan atau pilihan pengambilan keputusan adalah budaya, sosial, pribadi, dan psikologi (Kotler, 2012). Dari tahapan sebelumnya, ada beberapa hal yang menjadi pertimbangan partisipan dalam tahap ini. Ditemukan salah satu inti yang menentukan ketiga partisipan membuat pilihan yang akan dipilih untuk dijadikan keputusan akhir, yaitu memilih untuk menikah dengan istri tuna wicara.

Pada penelitian sebelumnya, yang menjadi dasar untuk memilih menikah dengan disabilitas adalah karena adanya keyakinan bahwa hal tersebut sudah digariskan oleh Allah SWT dan seseorang disabilitas mampu berperan sebagai pasangan dan mengerti akan tugas dan kewajibannya. Wujud rasa kasih sayang yang telah diberikan selama menjalin hubungan, sehingga pernikahan dipilih sebagai bentuk kesungguhan. Sebuah pernikahan terjadi proses interaksi tidak hanya pada hal yang positif saja, namun terjadi pada hal buruk juga (Prabowo, 2014). Pernyataan tersebut sejalan dengan suatu hal yang menjadi temuan dari hasil penelitian, yaitu tekad, keinginan, dan niat yang sungguh-sungguh serta rasa tanggung jawab kepada istri $\mathrm{H}$ menjadikan hal tersebut sebagai alternatif kebijakan yang dilakukan oleh H. Selain itu, walaupun dengan kekurangan fisik yang dialami oleh istri. $\mathrm{H}$ tidak menjadikan hal tersebut menjadi suatu masalah, sebab usia $\mathrm{H}$ yang sudah siap dan istri memiliki paras yang cantik membuat $\mathrm{H}$ memilih untuk menikahinya serta $\mathrm{H}$ berdoa dan percaya bahwa hal tersebut sudah menjadi jodoh $\mathrm{H}$ yang telah ditentukan oleh Allah SWT. Dan secara ekonomi $\mathrm{H}$ sudah siap untuk menikah dan keadaan ekonomi tidak dijadikan sebagai salah satu faktor untuk memilih menikah dengan istri tuna wicara.

Berbeda dengan A, yaitu keadaan ekonomi menjadi salah satu faktor untuk A menikah dengan istri tuna wicara, karena keadaan ekonomi A yang kurang mampu dan ingin memperbaiki keadaan ekonomi keluarganya. Selain itu, keluarga 
istri A juga tidak mempermasalahkan keadaan ekonomi A yang kurang mampu. Tidak ada permasalahan yang berhubungan dengan istri yang pernah terjadi dimasa lalu, melainkan permasalahan pada A yaitu semakin bertambahnya usia, keadaan ekonomi yang kurang mampu, dan masa lalu yang membuat A memilih menikah dengan wanita tuna wicara. Kemudian pada partisipan $\mathrm{S}$ memiliki pertimbangan yang menjadi permasalahan, yaitu karena merasa kasihan dengan istri, sebab umurnya sudah semakin tua, dan S merasa kesepian setelah meninggalnya istri pertama serta untuk memenuhi kebutuhan biologisnya. S melakukan pertimbangan dan bermusyawarah dengan keluarga untuk mengatasi permasalahan yang ada mengenai pengambilan keputusan memilih menikah dengan istri tuna wicara. Menurut Kotler (2012), ada empat faktor yang mempengaruhi pengambilan keputusan, yaitu; faktor budaya yang meliputi peran budaya, sub budaya, dan kelas sosia; faktor sosial meliputi kelompok acuan, keluarga, peran, dan status sosial dalam masyarakat; faktor pribadi yang termasuk usia dan tahap siklus hidup, pekerjaan, keadaan ekonomi, gaya hidup, dan kepribadian; kemudian faktor psikologis meliputi motivasi, persepsi, pengetahuan, keyakinan, dan pendirian.

Berdasarkan hasil penelitian yang dilakukan oleh peneliti, pengambilan keputusan partisipan dipengaruhi oleh faktor-faktor tersebut. Namun dari keseluruhan faktor, hanya terdapat tiga faktor yang mempengaruhi partisipan dalam mengambil keputusan menikah dengan istri tuna wicara, yaitu faktor sosial, faktor pribadi, dan faktor psikologis. Pada faktor sosial terdapat kelompok acuan, keluarga, dan peran dan status sosial dalam masyarakat. Kelompok acuan dapat berupa pertemanan, yaitu A memiliki teman di tempat kerjanya yang berawal dari permintaan orang tua istri A kepada teman A untuk mengenalkan istri A kepada A dengan tujuan untuk melanjutkan ke jenjang pernikahan. Kemudian hal tersebut disetujui oleh A dengan beberapa pertimbangan yang telah dipikirkan secara matang. Berbeda dengan $\mathrm{H}$ dan $\mathrm{S}$ yang memilih menikah dengan istri tuna wicara karena atas kemauan sendiri tanpa adanya dorongan dari orang lain.

Selanjutnya adalah faktor pribadi yang meliputi usia dan tahap siklus hidup, pekerjaan, keadaan ekonomi, gaya hidup, dan kepribadian. Pada usia dan tahap siklus hidup ketiga partisipan, yaitu $\mathrm{H}, \mathrm{A}$, dan $\mathrm{S}$ masing-masing sudah memasuki usia yang cukup matang untuk menikah dan dapat dikatakan mampu untuk memilih keputusan yang terbaik bagi dirinya serta dapat memikirkan dampak positif dan negatif yang akan diperoleh, sehingga keputusan yang dipilih oleh ketiga partisipan merupakan keputusan yang tepat dan sudah dipikirkan secara matang dan baik. Kemudian pada keadaan ekonomi A dan $\mathrm{S}$ menjadi salah satu faktor yang mempengaruhi pemilihan pengambilan keputusan. Pada A, karena istri A adalah anak dari keluarga yang berkecukupan dan hal tersebut berbanding terbalik dengan keadaan ekonomi yang dialami A, maka dari itu A memiliki alasan ingin memperbaiki keadaan ekonomi keluarganya dan memutuskan untuk memilih keputusan menikah dengan istri A. Sedangkan S menjadikan keadaan ekonomi sebagai alasan S untuk lebih giat bekerja mencari nafkah untuk mencukupi kebutuhan istri.

Kemudian pada faktor psikologis yang meliputi motivasi, persepsi, pengetahuan, keyakinan dan pendirian. Pengetahuan atau pembelajaran mencakup pengalaman yang telah dialami oleh partisipan A dan S menjadikan suatu pembelajaran untuk mempertimbangkan keputusan yang akan diambil kedepannya. Keyakinan dan pendirian dari niat ketiga partisipan menjadikan pilihan pengambilan keputusan tersebut adalah suatu dorongan dari dalam diri partisipan 
yang harus dijalani dengan rasa sabar, ikhlas, dan penuh rasa syukur, karna

partisipan percaya hal tersebut adalah jodoh yang telah ditentukan dari Allah SWT.

\section{Pemilihan Salah Satu Alternatif Terbaik}

Pemilihan salah satu alternatif terbaik, yaitu memilih satu alternatif yang paling tepat dan baik untuk memecahkan suatu permasalahan individu atas dasar pertimbangan secara matang. Dalam tahap ini membutuhkan waktu yang lama karena untuk menentukan alternatif yang dipakai akan berhasil atau tidak (Kotler, 2012). Pemilihan salah satu alternatif terbaik yang dipilih oleh ketiga partisipan adalah memilih menikah dengan istri tuna wicara yang sudah dipertimbangkan dan direncanakan secara matang-matang dengan memikirkan dampak positif dan dampak negatif yang akan terjadi.

$\mathrm{H}$, A, dan S memilih menikah dengan istri tuna wicara adalah keputusan yang tepat. Pada $\mathrm{H}$ dan $\mathrm{S}$ menikah berdasarkan atas keinginan diri sendiri dan niat baiknya untuk menjalankan sebuah kehidupan pernikahan. Saat memutuskan untuk memilih pilihan yang dianggap terbaik, individu mempertimbangkan dengan hati-hati mengenai pemilihan pengambilan keputusan tersebut. $\mathrm{H}$ dan $\mathrm{S}$ tidak pernah meragukan niat dan keinginan menikah dengan istri, karena sudah menerima kekurangan dan kondisi yang dialami istri, serta hal tersebut adalah jodoh dari Tuhan.

\section{Pelaksanaan Keputusan}

Pelaksanaan keputusan, yaitu tahap dalam proses pengambilan keputusan sampai individu benar-benar mengambil keputusan terbaik dan individu mampu menerima dampak positif dan negatif dari pengambilan keputusan tersebut (Kotler, 2012). Pengambilan keputusan menikah dengan istri tuna wicara memberikan pandangan sendiri mengenai hal-hal yang dirasakan selama melaksanakan pengambilan keputusan tersebut. Pada $\mathrm{H}$ menjalani kehidupan dengan santai, senang, dan tidak ada masalah besar di rumah tangganya. Begitu pula dengan $S$, yaitu menjalani kehidupan dengan kebahagiaan, bersemangat dalam bekerja, dan tidak merasa terbebani. Kemudian, A menjalani kehidupan dengan normal, namun tekadang A merasakan suatu hal yang berat hingga terbawa emosi akibat dari adanya salah paham dari pembicaraan antara A dan istri.

\section{Pemantauan dan Pengevaluasian Hasil Pelaksanaan}

Pemantauan dan pengevaluasian hasil pelaksanaan, yaitu perilaku individu setelah melaksanakan keputusan dapat mengukur dampak dari keputusan yang telah dipilih apakah sudah mencapai tujuan yang diinginkan atau sebaliknya (Kotler, 2012). Tahapan ini merupakan suatu bentuk tahapan yang membuat ketiga partisipan menyadari bahwa keputusan yang dipilih akan ada suatu dampak, baik dampak positif maupun dampak negatif.

Dalam menjalankan pilihan keputusan menikah dengan istri tuna wicara, $\mathrm{H}$ mendapatkan dampak positif dan negatif. Dampak positifnya adalah menjadi lebih sabar dan lebih bersyukur. Kemudian dampak negatifnya adalah sering mengalami miskomunikasi dengan istri dan sulit untuk berkomunikasi satu sama lain, karena menjalin rumah tangga yang baik perlu adanya komunikasi yang baik dengan suami dan istri untuk mencapai tujuan dan keinginan yang diinginkan. Setelah mengetahui dampak positif dan negatif dari menikah dengan istri tuna wicara, $\mathrm{H}$ mendapatkan kenikmatan, kesenangan hidup berkeluarga, dan bahagia memiliki anak, karena hal tersebut anugrah yang telah diberikan oleh Allah SWT. 
Kemudian dampak positif yang didapatkan oleh partisipan A adalah merasa senang setelah menikah karena telah memiliki anak, bersyukur, menjadi lebih sabar, dan saling menerima kekurangan. Kemudian A mengaku memperoleh dampak negatif, yaitu mendapat cibiran dari orang lain dan terkadang A merasa malu ketika ingin bersosialisasi dengan masyarakat, sehingga hal tersebut membuat A kurang percaya diri ketika ingin beraktifitas dilingkungan.

Berbeda dengan $\mathrm{S}$ bahwa belum ada dampak negatif setelah menikah dengan istri, sebab pernikahannya masih baru. Kemudian dampak positif yang $\mathrm{S}$ rasakan adalah rasa senang, sabar, dan saling memahami dengan istri. Sesuatu yang $\mathrm{S}$ ingin dapatkan adalah ingin mendapat keturunan dari istri, tetapi hal tersebut sangat tidak mungkin karena faktor usia $\mathrm{S}$ dan usia istri $\mathrm{S}$ yang tidak lagi ideal untuk memiliki anak

\section{KESIMPULAN}

Pada setiap partisipan telah melewati bentuk dari tahapan pengambilan keputusan, yaitu identifikasi masalah, pencarian dan analisis data, pembuatan alternatif kebijakan, pemilihan salah satu alternatif terbaik, pelaksanaan keputusan, serta pemantauan dan pengevaluasian hasil pelaksanaan serta dipengaruhi oleh faktor sosial, faktor pribadi, dan faktor psikologis. Pada $\mathrm{H}$ dan $\mathrm{S}$ menikah dengan wanita tuna wicara karena atas keinginan sendiri, sedangkan pada A menikah dengan wanaita tuna wicara karena dijodohkan.

\section{SARAN}

Berikut ini adalah beberapa saran yang dapat diberikan oleh peneliti berdasarkan hasil penelitian:

1. Bagi peneliti selanjutnya yang ingin meneliti tema yang sama dapat menggunakan variabel lainnya, yaitu antara lain kebahagiaan, komunikasi dalam pasangan suami istri, komunikasi sex, kebersyukuran, faktor pendidikan, dan adaptasi.

2. Bagi masyarakat yang memiliki keinginan menikah dengan seseorang yang memiliki keterbatasan fisik atau disabilitas, yaitu diharapkan penelitian ini mampu menjadi suatu pertimbangan yang matang dengan melihat dampak positif dan negatif dari sebelum dan sesudah mengambil keputusan menikah dengan seseorang yang memiliki keterbatasan fisik.

\section{KEPUSTAKAAN}

Creswell, J. W. (2013). Research Design: Pendekatan Kualitatif, Kuantitatif, dan Mixed Edisi ke-3. Yogyakarta: Pustaka Pelajar.

Kertamuda, F.E. (2009). Konseling Pernikahan Untuk Keluarga Indonesia. Jakarta: Salemba Humanika.

Kotler, P., \& Keller, K, L., (2012). Marketing Management $14^{\text {th }}$ edition. New Jersey: Pearson Prentice Hall Inc.

Manggala, M. C. (2016). Pemilihan Jodoh Di Kalangan Penyandang Disabilitas (Studi tentang Pemilihan Jodoh antara Pria Non Disabilitas dengan Wanita Disabilitas Anggota Himpunan Wanita Disabilitas Indonesia Cabang Surabaya). (Disertasi). Universitas Airlangga. 
Miller, R.S., \& Perlman, D. (2015). Intimate Relationships $7^{\text {th }}$ edition. Boston: McGraw-Hill

Prabowo, G. A. (2014). Konstruksi Sosial Tentang Perkawinan Disabilitas Tunanetra Di Surabaya "Studi Deskriptif tentang Makna Perkawinan Bagi Wanita Normal yang Menikah dengan Disabilitas Tunanetra Anggota PERTUNI." Universitas Airlangga. Disertasi.

Robbins, S. P., \& Judge, T. A. (2013). Organizational Behavior $15^{\text {th }}$ Edition. Wasington DC: Pearson Education.

Sardjono. (2005). Terapi Wicara. Jakarta: Depdiknas Dirjen Pendidikan Tinggi Direktorat Pembinaan Pendidikan Tenaga Kependidikan Dan Ketenagaan Perguruan Tinggi. 